\title{
Criticism and Psychology: the Understanding with a Postmodern Psychology
}

\section{Juan David Millán ${ }^{1}$ (D) - Jean Nikola Cudina ${ }^{2}$ (D) Julio César Ossa ${ }^{3}$ (D)}

Received: 3 April 2019 /Revised: 20 August 2019 / Accepted: 7 September 2019

Published online: 11 December 2019

(C) Springer Nature Switzerland AG 2019

\begin{abstract}
Frequently, "critical psychologies" question the ideological and political framework that develops and legitimizes certain mainstream psychology. Nevertheless, it is still a field of knowledge which has not been fully differentiated from its crisis - mainly-because an exhaustive ontological categorical demand has not been made. From the analysis of Ian Parker's critical discourse psychology (CDP) and critical psychology, we observed the causes and consequences of the introduction of scientific realism as an intermediate stage in the elaboration of what has been called radical metapsychological project or a general critic of psychology. We reviewed, from the quantitative method multi-RPYS references, an approximate of 51 papers and 10 books of Ian Parker's work analyzed by the web program RPYS i/o. From the start, CDP and PCL avoided the short form of the critic, which is barely a differentiation from the totality of dominant psychology. Instead, they announced, implicitly, some methodological and theoretical tools which could be useful to prevent its definite adhesion to postmodernism, where "anything goes" is its most manifest condition.
\end{abstract}

Keywords Psychology $\cdot$ Critic $\cdot$ Latin American · Discourse $\cdot$ Critical realism

\section{Abbreviations}

SC social constructionism

SR scientific realism

Juan David Millán

juanmillan561@ @otmail.com

Jean Nikola Cudina

j.nikolacudina@hotmail.com

Julio César Ossa

juceosssa@gmail.com

1 Psychology Program, Fundación Universitaria de Popayán, Popayán, Colombia

2 Corporación Niñez y Conocimiento, Bogota, Colombia

3 Psychology Faculty, Universidad de San Buenaventura, Cali, Colombia 


$\begin{array}{ll}\text { BSP } & \text { British Social Psychology } \\ \text { DP } & \text { discursive psychology } \\ \text { CDP } & \text { critical discursive psychology } \\ \text { SA } & \text { speech act } \\ \text { CMP } & \text { critical metaphysical project }\end{array}$

\section{Introduction}

The social psychology of the last decades has been based on a discursive and relativist tradition of science (Barad 2003). This is because social psychologists are reluctant to a proposal which does not include the socioconstructionism as its metatheory. On the other hand, this field is beginning to show more internal fissures which reveal the lack of an ontological premise and the progression of and academicism which makes social constructionism a flag which covers the inability to act on reality.

Reality and its effects place social psychology in a new paradigmatic crisis. Social constructionism ( $\mathrm{SC}$ from now on) is not to blame for the catastrophe of social psychology; on the contrary, it has long borne the hardship for having a weak ontology and the absence of a material and ethical nucleus. The only thing we can make it responsible for is, to a part of constructionism, to declare it incompatible with any form of ontology (Molina 2015; González-Rey 2009; Goulart 2013).

In the last decades, the initiatives of reactivating ontological projects in social sciences have proliferated and have had as their purpose the opposition to postmodernism, the epistemological values of the relativist and linguistic turn, the deconstruction, micropolitics, or everything related to the heritage of "French theory" (Castro-Gómez 2015; Parker 1989).

This proliferation of projects is nothing more than the result of the alienation and forgetting of a debate that is necessary to return. This is to discuss reality in social psychology as an ontological principle. Placing reality as an ontological principle in a social context like Latin America and the development of psychology in the specific context of each country in the region forces us to distance ourselves from any kind of theoretical relativism that goes against the clarification of social conditioning and psychological of human action and the search for truth (Martín-Baró 1973).

Therefore, in this paper, we assume the notion of a disagreement with a postmodern psychology. As a resource to develop this thesis, we return to Ian Parker's critical social psychology and the one from Discourse Unit, which have had the important role, in the criticism of postmodern psychology, of placing an ontology which allows them to tackle ideological and political problems which make capitalism progress from what has been denominated as Psy-complex (Parker 2007a, b).

The scientific realism (SR from now on) is another resource that we take that together with Latin American critical psychology is the element which intervenes in the elaboration of an ontological social psychology project. Furthermore, it avoids at all cost the derivation towards a metaphysical or transcendental ontology as in many cases they tend to finish projects like the Zizekian or Mario Bunge's ontology.

First, we will start by doing a critical epistemic assessment from the philosophy of science in social discursive psychology and in the critical orientation of the Discourse Unit. The critical epistemic assessment is a formal condition inherent to the scientific happening of a discipline, where its fundamentals are reviewed with the objective to avoid that a determined knowledge becomes a dogma (Montero 2004). 
For this, we use a systematic analysis of the specialized literature in the Scopus database. The analysis is carried out in two moments: namely, the first moment corresponds to an analysis of scientific communication networks (Cudina et al. 2017) to determine the structure and academic communities around the discursive psychology, through the Vosviewer software (van Eck and Waltman 2010). The second stage corresponds to an analysis to determine the theoretical influences within the Discourse Unit through the Reference Publication Year Spectography (RPYS) software (Marx et al. 2014; Comins and Leydesdorff 2016). In both cases, the empirical corpus in which the figures are represented constitutes bibliographical references.

\section{The Stage Character of Social Constructionism in Social Psychology}

The crisis of social psychology of the 1970s had the method as its core discussion (Silverman 1977). The debate consisted in the hegemony of the quantitative methods and the experimental method about qualitative methods of the studies of social psychology. This event favored an opportunity to create a certain "independence" from the disciplines which had contributed to the development of social psychology. However, it was so insufficient that it has been considered shortsighted to sustain a separated discipline from the historically bordering disciplines such as politics, sociology, and even economy (Gergen 2008).

Social psychologies, like most sciences with the name of social or human, were immediately located in social constructionism. Under this paradigm, many social psychologists affirm to have reached a solid terrain in the discipline, sustained by the effect of the research or the rising and not a negligible number of published papers (Molina and Estrada 2006). But it was rejected when considering the misfortune of the last decades that has circumscribed social psychology in an imprecise, lax, apolitical movement with changing contours (Ibáñez 1985; Íñiguez 2005). As affirmed by Parker, social psychology finds itself in constant crisis (Parker 1989).

Because of the way social psychology has been developed, it can only be considered a necessary and transitory state towards an instituted social psychology. This affirmation is sustained by the growing breach between the theory or epistemology proposed and the practice of the researchers in the qualitative constructivist paradigm (Wiesenfeld 2000; Calle-Álvarez 2013).

The statement affirming that social psychology has been a transitory stage is evident when the concepts in this field have been mainly elaborated by the argument of the difference and not as a result of the internal coherence or the affirmation of the proper gnoseological values. It is about generating a diamérica elaboration of social psychology, where the defined terms and settings of the field explain themselves the same for the same (Bueno 1972; Álvarez and Taboada 2016).

The state character of social psychology has a great responsibility in the constructionist epistemology, by placing it in the muddy terrain of skepticism, relativism, and monism of language (Niiniluoto 1991). This does not mean that a finished and definite version of social psychology is proposed by completely discarding SC but instead the need to purge some defects in its philosophical foundation, for instance the lack of immanence in the field regarding terms, relations, and operations (Bueno 1991).

\section{British Social Psychology: a Phenomenology for Social Psychology}

With the philosophy of science, we can say that social psychology, because of its elaboration, belongs to the field of fundamental phenomenological disciplines. This means that it has a 
special proximity with the phenomenon, appearances, and world facts, not only with its description but that it is the only thing given and to which it needs to constantly turn to. Generally, social psychology, when thought of as a field of knowledge and a closed system of "constructive operations," it is left in oblivion and in the hands of the historical determinations (Pérez-Jiménez 2002).

For these types of phenomenological sciences, an ontology where the phenomenon is taken as a form of being will be established, meaning that its ontology is constrainedly phenomenological. Then, these phenomena will remit to structures which are also phenomenal to define a background or closed essence. This model of "internal realism" is carried out by the British Social Psychology (from now on BSP) and radicalized by discursive social psychology (Potter 2012). The proximity of the BSP with the science of philosophy, in particular, scientific realism and its marked Kantian background, makes it recover the existing transcendent breach between the subject and the reality $(\mathrm{S} / \mathrm{R})$, as the most important epistemological problem that has arisen in modernity (Abrams and Hogg 1990a; Potter 2010a).

Unlike social psychologies, centered in Latin America, Spain, and North America, the British Social Psychology did not evidence a crisis centered in the method. Studies from the 1970s and 1980s developed by BSP showed the coexistence of experimental and qualitative methods, in addition to the progression of John Austin and Wittgenstein's ideas regarding ordinary language and the anti-philosophical movement represented by these authors (see Sabucedo-Camellese 1989; Fernández-Villanueva 2003; Potter 2010b).

Even though there is a heterogeneity of methods that come together in BSP, the analysis of the discourse is the one which was consolidated as the most radical (Parker 2014). Although it accentuated the characteristics of social constructionism, it brought back the epistemological discussion given in the interior of scientific rationality in modernity, which has made way, in the last decades, from the critical side to the introduction of subjectivity which had been displaced by structuralist focuses of language (Abrams and Hogg 1990b; Chouliaraki 2002).

For discursive psychology (from now on DP), in particular, from the historical sociology of science and in a smaller scale of the linguistic or discursive turn, the analysis of the discourse became like most theories of methodological and theoretical postures in human sciences from the middle of the XXth century (Potter 2012; Klempe 2018). This is a differential characteristic regarding the "other social psychologies," as long as concepts concerning epistemology, truth, realism, relativism, or the nature of knowledge, are resumed in a constant way and intervene in the development of discursive psychology (Potter 2009). If we look at the production of the DP which according to Potter (2011) ranges from 4000 academic journals and 500 book chapters, it enables us to approach its current development. In this case, Fig. 1, which was made from the data gathered from Scopus and was analyzed with the program Vosviewer, points out the distribution of communities of hidden networks in the production of discursive social psychology and signifies the heterogeneity in a field in which there is predominance in the speech act (see Fig. 1).

As we can see in Fig. 1, the red cluster with a higher density is the one that refers to the sector of the critical discourse psychology (CDP). The yellow cluster represents the discursive psychology in its most social constructionist version. A very strong cluster is the conversational analysis based on the speech-exchange systems (Sacks et al. 1974). This theory carries out a synthesis between Austin's philosophy of speech acts and Talcott Parson's sociological theory to lead to a hypothesis about the social cognition and the social structure (Shegloff 1991). For DP, we defined three logical and nonchronological moments in its development. 


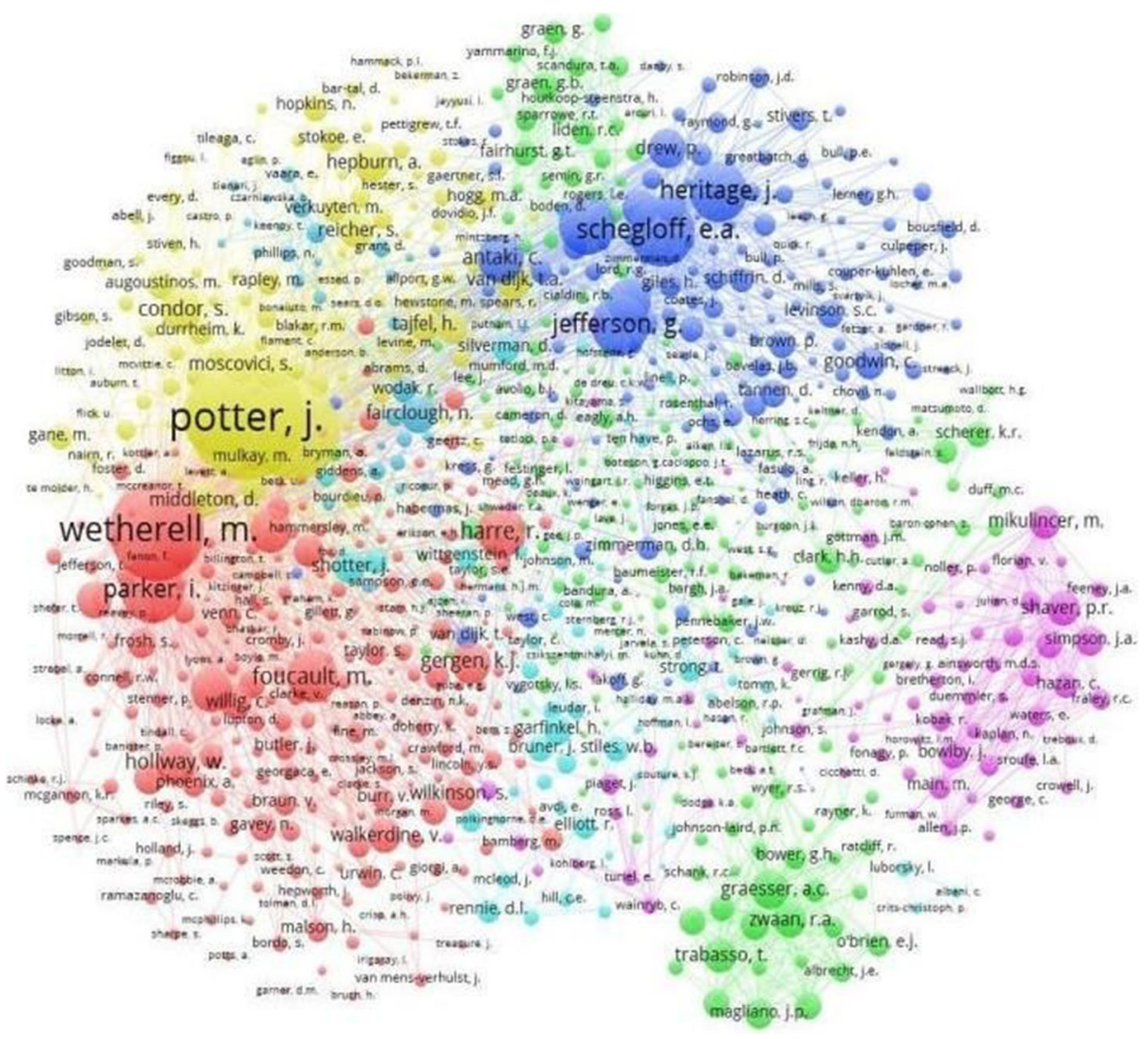

Fig. 1 Map of the co-citations in the current production of discursive psychology. Source: self-made

In the first moment, Mike Mulkay and Nigel Gilbert have the deployment of the analysis of the discourse in social psychology and in sociology. Its consolidation was a consequence of the elaboration of an empirical program which described and documented how varied interpretative repertoires are used and can be adopted in different social frameworks by different participants and in different historical periods to know about a determined phenomenon or fact (Shapin 1984).

The first stage of PD as affirmed by Rom Harré makes part of a "Second Cognitive Revolution," which privileged the study of ordinary language and its positive manifestations and, additionally, offered an explanatory framework of the public and private experience of the mental states as realized by the studies about communication, cognition, and social interaction (Harré 1994). This project had at least two controversial elements. First, versions and interpretations found should be regular and definite as these are similar to the scientific discourse. Second, the considerations of the political, social, and psychological phenomena are distortive factors of little importance of the analysis of the discourse (Mulkay 1981; Villalobos 2013).

The second stage of the gestation of PD had discussions about the epistemological subject and the "nature" of the reality it knows (Harré 1984; Travis-Harré 1985). The discussion mentioned brought back some matters that conditioned the birth of scientific rationality in modernity, mainly the objectification as an epistemological problem emerging from the 
relation subject-object (S/O) ${ }^{1}$ (Harré 1984; Parker 1989; Potter 1985). The objectification implies "to make anything an object," meaning defining a regional ontology where concepts and categories are specified to know an object (Ruíz and Enrique 2002).

In the third and last stage of DP, most of the topics surrounding the epistemological relation and the problem of the objectification were settled and forgotten by the substitution of the epistemological subject by the conception of a natural agent, the use of the speech act as a phenomenon and intimate manifestation of the latter, and the pragmatic or performative construction of reality.

The performative character of the speech act is obtained from the fact that the announced thing obtains its reality from the enunciation itself. The performative act contemplates two dimensions: the position or status of the speaking subject and an institutionalized context in which a determined speech act makes sense (Foucault 1972). Consequently, the effects obtained from a statement are known beforehand by the context which has already coded it. An example of performative action, Session is open!, a judge dictates is the same result as the statement, the session is open. For this, the act of the statement is required to be effected in a room where jurisprudence is dictated and the one who is conducting it is a judge.

Parker, who is inscribed in the second logical moment in DP, realizes a critic to the ethnogenic perspective of Rom Harré, who just like the act of language configures a "drama" governed by some few common rules. As a consequence, the research developed in these frameworks is restricted to the search of the rules which underlie the organization of meanings but leave out the intentionality of the subject (Parker 1989). Finally, these proposals of DP are extremely conservative as long as ordinary language and its manifestations embody all men's reality and are precisely in the field of consensuality and everydayness where the practices of alignment and oppression are legitimized.

The theory of John Austin and Searle's act of speech founded for DP a phenomenology is based on the "act of being," an "in itself" that enables a closing for the transcendental breach of knowledge of reality for modern subjectivity. When the transcendental breach, which was established with reality, disappears, we also lose the possibility that the subject can act on the same one. The notion of the modern subject is superseded by an "agent" subject deploying its "powers" to build a reality, a premodern materiality in the sense that it makes the world a species of animism.

This animism can be contemplated in the thesis about the structuration of social systems as self-organizing and autopoietic systems, where causes are non-contingent with its consequences and resulted in being incapable of finally introducing a real operation ${ }^{2}$ in reality.

We have as the effect of premodern materiality — which poses postmodernity — an "anthropomorphized" reality understood as an extension of acting, construction, configurations, creativity, etc. of the agent subject. Shotter, Harré, and Secord coined, in the 1980s, the concept of "personal powers" to denominate the effect of what they defined as the natural agent.

I shall propose instead that we characterize human beings by the fact that they possess a natural power to construct or create in interaction ... a personal power to control their performances in accordance with rules (Shotter 1973, p. 142).

\footnotetext{
${ }^{1}$ We will use the resource of the " $"$ in the sense of the Sausserian structuralist linguistic, to indicate the impossibility of the reduction between the subject and the object.

${ }^{2}$ We define operation as an authentic "action" in three moments: intentionality, enabler of effects, and a reflexive moment.
} 
The "being in the act" from Aristotle poses a luck of "mundane monism" in which elements and configurations of reality and the action of the natural agent end up relating to everything. The speech act as an ontic-ontological unit taken by DP to develop its practical horizon is based on an isomorphism between the agent subject and objective reality (S-O). ${ }^{3}$ Consequently, the speech act (SA from now on) becomes an imminent act to reality (S-SA-O), a totality with the subject and object according to what Ian Parker denominated as an image of the current virtual capitalism (Pavón-Cuéllar 2014).

DP is constituted in a logical, pragmatic, and formal state of a materialistic and dialectic ontology which has had its most fruitful development in the fields of politics and philosophy when regaining the truth and expanding the existing epistemological breach between objective reality and subjectivity. The speech act is presented without gaps, like a totality full of sense; besides, it institutes a premodern realism which manages, in this case, and bares itself of pressing matters like the truth; and it poses a skepticism regarding effective reality (Wirklichkeit).

For DP and in general for social psychology, this step towards a materialistic dialectic ontology is more difficult because the "speech act" is kept as the most important conceptual unit and has consolidated a practical and analytical horizon. The theory of the speech act is a purely factual theory and has led to an empiricist misplacement, as long as it is claimed as the final stage of the formal and abstract analysis of the "concrete real" (Laclau 2001).

DP defines a formal stage of the reality of very similar characteristics to those of Peirce, Habermas, or Apel in which the intersubjectivity is the validity criterion for the formation of a communicative community in which truth results in being a linguistic fact, given by mere consensually "truth of a determined language" (see Dussel 1998).

It is precisely the comfort offered by the speech act which makes DP not precipitate in a search for an ontology and a search for the truth in its realistic acceptance. SA also indicates the horizon of postmodern materiality which decants every time more and more by a philosophical monism in which basically "everything is related to everything" granted the appearance of a harmony between the world and the phenomena which compose them.

As established by John Shotter's lecture about Bhaskar, critical realism allows the "recovery" of reality and places it in the ontological level of what is implacable, capable of surprising us, and in the second instance, it can generate a control over it (Shotter 2001). But it can go beyond when posing a reality less anthropomorphic.

Approaches from DP are interesting as long as it develops in its interior some elements to retake the rational core for a critic of premodern materiality which proclaims certain sectors of DP. One of these is Ian Parker's critical psychology which had its first theoretical tool in scientific realism. Curiously, the same theory configured the first and second moments in DP. In this sense, DP results are interesting for a general critical project; thus, it constitutes its formal stage.

The formality in philosophical logic is understood as the propositions and theories that are analyzable according to the form and not the contents. In this sense, Parker's psychology makes a double connection between pure formality of DP and pure substance or practicalmaterial content of Latin American psychology.

Community psychology, liberation psychology, and critical social psychology are considered a Latin American paradigmatic expression of psychology. Despite that each one had different times of "foundation," it coincides - in a common way - in which the crisis of social

\footnotetext{
$\overline{3}$ We used "-" to indicate progression or reduction of a term in another one.
} 
psychology in the 1970s had its triggering event (Montero and Serrano-García 2011). Even though Latin American critical psychology had its context particularity and social reality that existed in most Latin American countries, the common elements that ended up forging an "identity" for the Latin American psychology are the critic, the praxis, and the political commitment (Montero 2010; Lane and Sawaia 1991).

The critical Latin American psychology also questions the relentless way the ideological role that psychology constitutes for the development of late capitalism, but contrary to Parker, it does not ensure a destruction of psychology itself. Freiriana's awareness to Monteriano's empowerment poses a moral practice about humanity, exclusion, and inequality. Silvia Lane and, as a Jesuit, Matin Baró's critical psychologies sustain a metaphysical position about the human being, founded in its concreteness, materiality, and exteriority. Ian Parker's work is analyzed in three specific dimensions: reality, subjectivity, and method.

\section{Critical Discursive Social Psychology or Critical Psychology}

The development of DP enabled the institutionalization through research groups. The Discourse Unit, a workgroup led by Ian Parker and Erica Burmann, has been characterized by consolidating the interdisciplinary and critical work strengthening efforts to inscribe the political action and the ideological critique within psychology. The Discourse Unit's principal communication channel is the Annual Review of Critical Psychology journal. It begins its critical task when the epistemological discussion restarts within DP. Figure 2 is a spectrogram made from the references of a total of 52 of Ian Parker's papers and books found in Scopus from 1984 to 2016.

We can observe that from 1992 to 1994 there is a significant rise in the number of references. This rise of references refers to Rom Harré and Roy Bhaskar's works, which largely have an argumentative and decisive function in the works dedicated to postmodern criticism (1990-1999). But they are placed in suspense and cited without any argumentative relevance in subsequent works. In Harré's case, he is only cited as a historical reference where Bhaskar is left in oblivion.

Bhaskar and Harré proposed two types of realism to determine the structure and location of the agency in the social activity. Harré posed a "conversational realism" while Bhaskar posed a transcendental conception of the social being (Varela and Harré 1996). We understand the term transcendental in its positive acceptance, opposed to any form of metaphysics. Transcendental reality is established from recurring determinations (a posteriori) which overgrow the immanence of place and time but that necessarily have their origin in the positive experience (Bueno 1991).

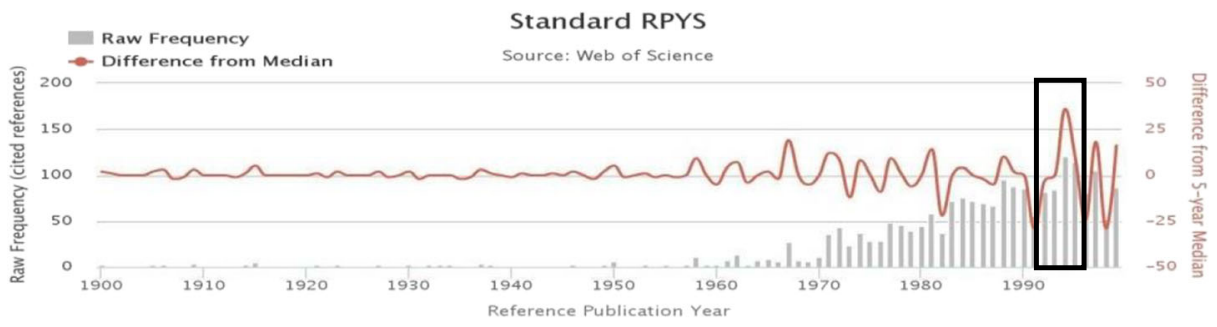

Fig. 2 Intellectual trajectory of the Discourse Unit 
Scientific realism posed by Bhaskar is completely skeptical for the subject to access beyond what the symbolic activity allows. He calls the epistemic fallacy the tendency of reducing the "existing" to what the subject has access to from the epistemic activity or the social activity of the agent subject. There is some luck in the substantive reality which is left as the remains of the symbolization and cannot be reduced to any conversational reality or communicative act; Bhaskar calls this reality intransitive reality.

Although intransitive reality is immeasurable for the human agency, this one has causal powers in transitive reality. Contrary to Harré's thesis about the agency or the powers of people as constituents of social entities and in general of the world, Bhaskar and Parker argue that the possibility to generate a true agency is possible as long as we increase the distance and otherness with reality to which we are supposed to know and act on (Bhaskar 2008).

As an epistemological doctrine, scientific realism postulates that the physical, social, and psychological worlds exist and have independent properties of the concepts and theories used to know them (Greenwood 1992). From this perspective, the "discursive practices" are related to culture, language, and meanings, and the "material practices" are independent but are related to the construction of reality (Sim-Schouten and Riley 2007). Ian Parker would be more radical at this point if he made a defense for the global ontological relationship of reality where it is not sufficient to say that there is a world but rather to make of it the first step to an approximation of how it organizes itself (Parker et al. 1990).

Roy Bhaskar's critical realism of his theory on scientific realism was constituted in a fundamental rhetorical element in Parker's dispute with Potter et al. (1991) and Hoggs (1990) about the reality of the "object" in DP. Parker found in critical realism theoretical elements not only to pose the ontological status of the object of analysis of the speech but also to undertake the introduction of a mainly political ontology within DP. It is not enough to recognize that it is possible to deduct a type of latent ideology in conversational texts, as done by DP, but that according to Parker, it is necessary to take a political position, a "moral edge," even "utopia" as any other political philosophical project. "An assessment of the political advantages and disadvantages of the different positions does require some kind of realistic stance" (Parker 1999, p.5).

To introduce the cleavage between reality and the following point which is subjectivity, it is necessary to resort to Michael Foucault and his relation to Kant. One of the most important rhetorical tools of the Discourse Unit is Foucault; nevertheless, his use is restricted in a predominant way to "first Foucault"; thus, the works with the highest number of citations are The Archaeology of Knowledge and Discipline and Punish (Foucault 1972); this is no minor detail if we consider that what prevailed in Foucault's approaches in these works were as follows: the war-like approach of the relations between power and the construction of reality in a particular way. This war-like model institutes, on the one hand, the impossibility of instituting a resistance which has not been contemplated as a product of power itself (Decoteau 2018).

Through the recovery of a more radical Kant - the same one who stresses the epistemological problem - the second Foucault enables an escape to the problem of the circularity of power when posing the type of subjectivity that, from the cultivation of itself or from the technologies of the self, obtains a space of resistance (Varela 2013). So the modern epistemological breach $(\mathrm{S} / \mathrm{O})$ will always be needed to institute a true action, but not necessarily taking the solipsist way of the latter Foucault, but it is necessary to introduce one more element. Ian Parker and David Pavón Cuellar conceptualized this element in the elaboration of what has been called the critical metaphysical project (from now on CMP). 


\section{Operative Corporal Subject}

The definition of subjectivity from CMP has assumed a universality, in many occasions with a marked Christian and theological content. This has probably been the element that distanced Parker from Zizek as the latter decanted every time more due to a Christianization of Lacan (Parker 2004). Parker sees in it an impossibility to carry out a true critic of capitalism, which does not derive in a new form of spiritism. It is the turn to the "open door" left by Marx as affirmed by David Pavón-Cuellar, the one that enables the horizon to a more demolishing critic to capitalism (Pavón-Cuéllar 2011).

The subject which contemplates this general critic is the one of an operational subject, which acts and develops its activity about other objects from its exteriority. The operational subject is the protests in the political community, a species of willpower which does not try to generate a domain over others but generate political spaces in which we can effect certain hegemony over the institutions as a positive acceptance of power.

The linguistic turn and the structuralist posthumanism had generated a subject which being part of materiality of the world lost the first moment of its constitution, the corporeality. In this point, we consider that many theories from the Lacanian Marxism decouple from the transcendental exteriority of the corporeal subject posed by Marx, which enables the liberation. This position is the only thing that provides a possible emancipation and not a liberation. The logic of the emancipation is the denial of the denial in the capitalist system; nevertheless, denying what has been denied in the capitalist system is equal to the last-minute affirmation of the system (Dussel 1996). In this sense, when CMP poses the liberation from a foreign exteriority to the capital, it locates itself as the final horizon in the elaboration of a generalized critic, the postulation "Contemporary capitalism demands more than simple abandonment of old models of the individual. There has been just as dramatic a transformation in the moral texture of neoliberal subjectivity" (Parker 2009, p. 15). The level of subjectivity must necessarily take a turn beyond the one that it gave in social psychology in the 1970s; as Parker affirms, it must go beyond the abandonment of models of individuality or postulating the community as telos of emancipation. Here, Marx has a lead role in the definition of the universality of the human being: the "being" is the non-being of the worker, meaning the definition of subjectivity starts with a negativity which has a pretension of universality.

The negativity contemplated from CMP and Enrique Dussel's Latin American philosophy is transcendental to the consideration of the proper workforce; its material content is the one of human life (bios), the one of "sensible corporeality," being vulnerable, being a sufferer, victim, and faceless, the true tragic dimension denial of the capital (Dussel 2008).

Parker uses the concept of alienation to place how the subject is produced within the Psycomplex and in general within late capitalism. However, the alienation effected by psychology as an ideology is constituted in a secondary formal moment of the domination of the capital; for this alignment to be effected, the subject must have been objectified previously as "being"of-capital, meaning it has been incorporated in the capital. Parker is skeptical at this point; alienation is not merely the separation from ourselves and from others but the kind of separation from ourselves wherein we experience ourselves as inhabited and driven by forces that are mysterious to us (Parker 2007a, b).

In effect, the alignment produced by psychology is secondary to the process of subsumption that effected the capital; it is precisely Marx whose manuscripts of the 44 denominates this transcendental exteriority as living work, something undetermined and exterior to the capital, and produces value from nothing from the capital, in contrast to the concept workforce which 
generates value from the capital (Dussel 1990). In this sense, Parker does not conceptualize man as abstract - but it is precisely "the forces that are mysterious to us" that means it is a movement which deprives man over a materiality which is its own negativity.

This subjectivity is necessarily exterior and transcendental to capitalism, recovers what has been denominated as the theory of Marx's needs, and shares certain similarity with Agamben's Homo Sacer where both figures are defined by their vulnerability; nevertheless, they are different because the concept of Dussel's immediate life from his lecture of "the last Marx" has in its needs, the social and political demands of its positive correlate, always palpable to indicate the oppressing nature of the capital. We would have to add to this immediate dimension of life, a normative dimension in which the being or the life community must take over - responsible - of their own life, project or class of conscience, and ensure the means to persist in the existence (Dussel 2009).

Lacanian psychoanalysis in Parker assumes a subjectivity operated by the absence or significant emptiness. While this generalized critic comes from a practical-material component, this does not obtain that characteristic in an a priori way but it takes it in a retroactive way and under strategic conditions: "...speaking of the empty space that sublimation as a process aims to fill, Lacan points out that religion in all its forms consists of avoiding this emptiness" (Parker 2011, p.153).

We avoid falling into a Manichaean romanticism with any pretension of establishing a teleology of the Latin American being or of the human being in general. Therefore, the suffering corporality is established as a significant emptiness which obtains its signification or certainty point in a retroactive way; thus, every material content will be different in every historical or hegemonic moment and each one of them will be established as universal.

What we propose is, firstly, to relocate the discussion about the need to recover the transcendental breach between subjectivity and reality $(\mathrm{S} / \mathrm{O})$ and to keep it as a formal structure and, secondly, to relocate the figure of the corporeal subject (leiblichkeit) then operative as substantiation of a critical subjectivity (Bueno 1972).

The conceptualization of the discourse dynamics in Parker's work has different facets; it is possible to elucidate the most valuable tools for the construction of a rational-formal and methodological nucleus for critical psychology. The first one was constituted in a follow-up of the epistemological constructionist currents of discursive social psychology, but its link to radical currents made its "apparent" instrumentality have decisive effects in what has been called its task of de-ideologizing.

The emergency of the discourse analysis and the ongoing influence of the ideas from linguistics and poststructuralism about "users" provide the foundation on which the discursive analytical investigation can be developed productively [...]: the descriptive, analytical, and educational function of the discourse analysis (Parker 1990, p. 189).

This, one of Parker's first texts, does not possess the sense which will later be given by Parker when he postulates the Lacanian analysis of speech as his most radical method (Parker 2005). The fact of using the word "practitioners" makes us assume an instrumental and pragmatic use of language. The instrumental use of language against the criticism it has received from a section of postmodernism has a clear purpose to create hegemony. In this sense, Antonio Gramsci postulated that the question of language should be planted - firstlyfrom its technical aspect (Gramsci 1971). The Marxist political theory, in pragmatics, finds a path to determine the practical difference between every theory and ideology in the framework of a formal methodology. In this sense, Gramscian theory would be closer to an approach of language the way it had been proposed by Potter and Wetherell's DP and the "first Parker" in 
the sense that the objects are constructed in the speech and in the text in the way of executing actions.

Parker and Erica Burman suggested a work definition of speech from texts from the early 1990s: "declaration systems with which an object is constructed," meaning a grammar which constitutes the objects and mediates any contact with reality (Parker 1996; Burman and Parker 1993). These papers are strictly methodological and directed to the research practice; in addition, they tense the definition of discourse, particularly the statute of the reality of the objects it conceives.

Hoggs, Potter, and Wetherell cast several critics, beginning with the statute of reality which Parker esteems in the layers of his critical analysis, in particular, when the problem of the synthetic identity of the speech is formulated, meaning it can be considered such and even up to what point that consideration goes to. This first stage also received critics because of the lack of functionality and the reification of speech. The notion of speech as a declaration system was pointed out as an extremely abstract system (Potter et al. 1990).

The Lacanian analysis of discourse posed later privileges the form of speech above its contents or the privilege of the formal qualities of the texts above all sense (Pavón-Cuéllar 2014). The proposal of the significant emptiness is a needed and real moment in the ideological critique, but as Dussel affirmed, we take the risk that parting from a discursive ontology, we might miss the possibility of building a positive political ontology.

This positive political ontology should be given by a founding moment (potestas), where at least it ensures a consensus of wills, and therefore, the meaningful emptiness shifts to having a full representation, a new common sense. In this sense, Parker's method is a negative dialectic moment of a methodology.

\section{Discourse Unit: a Formal State for an Architectural of Generalized Criticism in Psychology}

Parker's work relocates the discussion regarding the possibility of knowing and acting on reality within discursive psychology and constituted itself in its first critic to absolute relativism which was generated within psychology (Parker 1999). Roy Bhaskar's critical realism featured in the first works of Ian Parker's critical psychology contributes, on the one side, formal content of the first state of a systematization of critical psychology, when it places reality as the conjunction between the intransitive and transitive.

Table 1 shows an elaboration of what would be called a generalized critic. With Marx, the table follows a rising logic of the abstract towards the concrete: Ian Parker's critical psychology together with community psychology. The hypothesis is that critical realism, through Marxism, psychoanalysis, Michael Foucault's "romantic realism," and in a great measure by Latin American critical psychology, mutates a concept of a closer RC to the materiality and negativity of the victims of capitalism and circumscribes psychology in a historical perspective.

\section{Discussion}

For this discussion, we must follow an inverse path; we will start by saying that the critical Latin American reason taken by CPM is greatly decanted by affirming an original ethical 


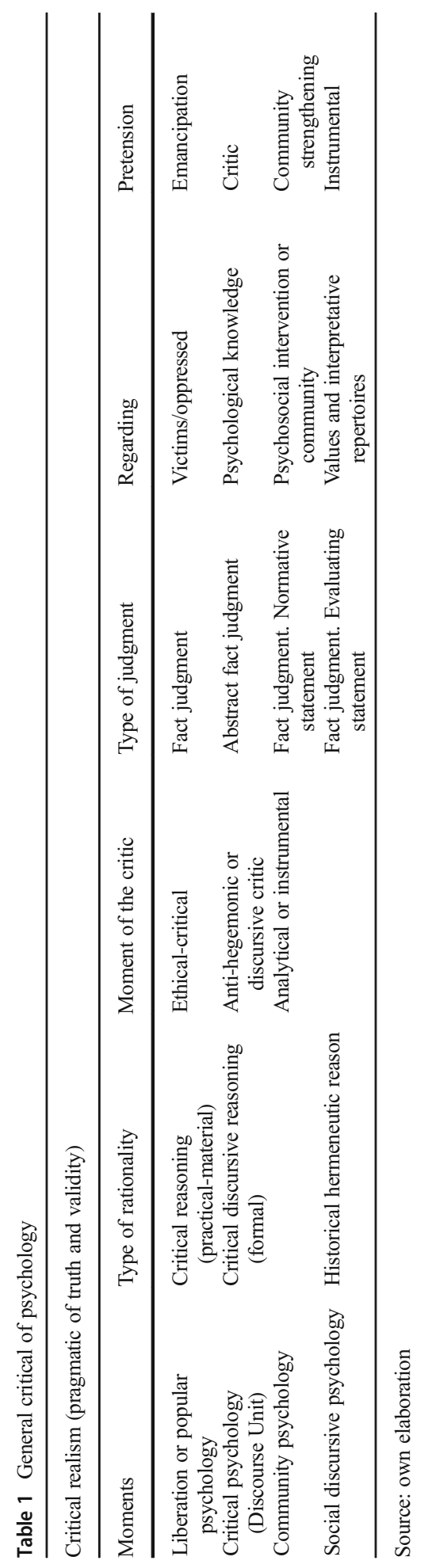


nucleus from a tremendously religious character, even though Marx affirmed that Bakunin's militant atheism concludes by removing the believing masses. Then, in the same sense, Dussel (2009) affirms that you cannot ask Latin American people to first be atheists and then revolutionaries; this type of ethical optimism, however, as affirmed by Santiago CastroGomez, generates a self-deception to the true moral and delayed reality of many Latin American countries (Castro-Gómez 1996).

Should the formal and metatheoretical state elaborated by the Discourse Unit be retaken from here, in particular Ian Parker, the distinction between ethic and moralization is the formal criterion of what is posed by the counselors of the critic and reflexive relation of critical psychology with itself and reality (Pavón-Cuéllar 2014; Parker 1999).

This project of generalized critic which has its inspirational source in radical metapsychology should supply itself with hermeneutic tools that enable a new academic and practical research field. This is where the most important rhetorical resource in critical psychology is required, Michael Foucault. We know that the French thinker studied the rules which configure the truth of a speech and, thus, avoid all type of substantial identity constructions such as Christian ethos which has configured a significant proportion of Latin American critical rationality.

This Latin American ethos configured by thinkers such as Enrique Dussel, Ignacio MartínBaró, and Silvia Lane has in the discovery of an ethical-material nucleus the search of psychological and philosophical systems fully exterior to scientific modernity but that in many cases ends up reproducing the values of the modern episteme when postulating a unique universal subjectivity. Here, the Lacanian resources of the significant and overall Lacanian Marxism aid in postulating an equivalence between other forms of materiality without forgetting the universal material content that each one of the proposals represents.

Therefore, Ian Parker's attitude and the Discourse Unit are modern as long as it makes what Foucault called present ontology from the lecture of the text Kant its own. What is illustration? What consists in implying the subject which lives in a determined time to question and be in charge of it (Margot 2015)? The bridge proposed in this study from CMP to Latin American critical rationality forges the possibility to carry out Parker's sentence that liberation psychology should not be psychology, rather, something better.

\section{References}

Abrams, D., \& Hogg, M. A. (1990). Social Identitiy Theory: Constructive and critical advances. London: Pearson Education Limited.

Abrams, D., \& Hogg, M. A. (1990a). Social identification, self-categorization and social influence. European Review of Social Psychology, 1(1), 195-228. https://doi.org/10.1080/14792779108401862.

Abrams, D., \& Hogg, M. A. (1990b). The context of discourse: let's not throw out the baby with the bathwater the context of discourse: let's not throw out the baby with the bathwater. Philosophical Psychology, 3, 219-225.

Álvarez, G., \& Taboada, M. B. (2016). Propuestas didácticas mediadas por tecnologías digitales para el desarrollo de competencias de lectura y escritura académicas. Revista Cientifica Guillermo de Ockham, 14(2), 83-91. https://doi.org/10.21500/22563202.2336.

Barad, K. (2003). Posthumanist performativity: toward an understanding of how matter comes to matter. Signs: Journal of Women in Culture and Society, 28, 801-831.

Bhaskar, R. (2008). A realist theory of science. Abingdon: Routledge.

Billig, M. (2012). Undisciplined beginnings, academic success, and discursive psychology. British Journal of Social Psychology, 51, 413-424.

Bueno, G. (1972). Ensayos materialistas. Madrid: Taurus Ediciones S. A.

Bueno, G. (1991). Ontológica. In B. Riojana (Ed.), Primer ensayo sobre las categorías de las "ciencias políticas” (pp. 119-127). Logroño: Biblioteca Riojana. 
Bunge, M. (1993). Realism and antirealism in social science. Theory and Decision, 35, 207-235.

Burman, E. (2008). What discourse is not. Philosophical Psychology, 4(3), 37-41.

Burman, E., \& Parker, I. (Eds.). (1993). Discourse analytic research. London: Routledge.

Calle-Álvarez, G. (2013). Construcción de argumentos durante la producción de textos digitales. Revista Cientifica Guillermo de Ockham, 11(2), 101-114. https://doi.org/10.21500/22563202.613.

Castro-Gómez, S. (1996). Crítica de la razón Latinoamericana. Barcelona: Puvill Libros.

Castro-Gómez, S. (2015). Revoluciones sin sujeto. Slavoj Žižek y la crítica del historicismo posmoderno. México: Akal.

Chouliaraki, L. (2002). 'The contingency of Universality': some thoughts on discourse and realism. Social Semiotics, 12(1), 83-114. https://doi.org/10.1080/10350330220130386.

Comins, J., \& Leydesdorff, L. (2016). RPYS i/o: Software demonstration of a web-based tool for the historiography and visualization of citation classics, sleeping beauties, and research fronts. Scientometrics, 107(3), 1509-1517. https://doi.org/10.1007/s11192-016-1928-z.

Corcoran, T. (2009). Second nature. British Journal of Social Psychology, 48, 375-388.

Corcoran, T. (2010). What else life if not awkward? British Journal of Social Psychology, 49, 679-684.

Cudina, J. N., Millán, J. D., \& Ossa, J. C. (2017). Redes de comunicación científica en la investigación psicológica de las Américas a través de la Revista Interamericana de Psicología. Revista Interamericana de Psicología, 51(3), 282-296.

Decoteau, C. L. (2018). Conjunctures and assemblages: approaches to multicausal explanation in the human sciences. Political Power and Social Theory, 34, 89-118. https://doi.org/10.1108/S0198871920180000034005 .

Durrheim, K. (2012). Discourse, action, rhetoric: from a perception to an action paradigm in social psychology. British Journal of Social Psychology, 51, 456-462.

Dussel, E. (1990). El último Marx (1863-1882) y la liberación latinoamericana (Un comentario a la tercera y a la cuarta redacción de "El capital."). México, Siglo veintiuno editores, s.a. de c.v.

Dussel, E. (1996). Filosofía de la Liberación. Bogotá: Editorial Nueva america.

Dussel, E. (1998). Ética de la liberación en la edad de la globalización y de la exclusión. Madrid: Editorial Trotta.

Dussel, E. (2008). Marx y la modernidad. Conferencias de la paz. La Paz: Rincón ediciones.

Dussel, E. (2009). Política de la liberación.Volumen II La arquitectónica. Madrid: Editorial Trotta, S.A.

Fernández-Villanueva, C. (2003). Psicologías sociales en el umbral del siglo XXI. Madrid: Fundamentos.

Foucault, M. (1972). The archaeology of knowledge. New York: Pantheon.

Foucault, M. (1995). Discipline and punish: the birth of the prison. New York: Vintage.

Gergen, K. J. (2008). A psicología social como historia. Psicologia \& Sociedade, 20(3), 475-484.

Greenwood, J. (1992). Realism, Relativism and rethoric: a response to comments on "realism, empiricism and social constructionism". Theory and Psychology, 2(2), 183-192.

González-Rey, F. (2009). Epistemología y Ontología: un debate necesario para la Psicología hoy. Diversitas: perspectivas en psicología, 5(2), 205-224.

Goulart, D. M. (2013). Autonomia, saúde mental e subjetividade no contexto assistencial brasileiro. Revista Guillermo de Ockham, 11(1), 21-33. https://doi.org/10.21500/22563202.599.

Gramsci, A. (1971). El materialismo histórico y la filosofia de Benedetto Croce. Buenos Aires: Ediciones Nueva Visión.

Harré, R. (1982). Ethogenic methods: an empirical psychology of action. In T. B. Psychological \& Society (Eds.), Social Psychology A practice manual (pp. 75-89). London.

Harré, R. (1984). Some reflections on the concept of "social representation". Social research, 51, 927-938.

Harré, R. (1992). What is real in psychology. A plea for persons. Theory \& Psychology, 2(2), $153-158$. https://doi.org/10.1177/0959354392022002.

Harré, R. (1994). Emotion and memory: the second cognitive revolution. Royal Institute of Philosophy Supplements, 37, 25-40.

Harré, R. (2009). Saving critical realism. Journal for the Theory of Social Behaviour, 39(2), 129-143.

Harré, R. (2015). "It's all discursive!" crossing boundaries and crossing words with Rom Harré. Universitas Psychologica, 14(2), 755-768.

Ibáñez, T. (1985). La psicología social: ¿en busca del paradigma perdido? Cuadernos de Psicologia, (1), 59-78.

Íniguez, L. (2005). Nuevos debates, nuevas ideas y nuevas prácticas en la psicología social de la era. Athenea Digital, 8, 1-7.

Klempe, S. H. (2018). Postmodernism and crises in psychology. Human Arenas, 1, 373-385.

Laclau, E. (2001). La razón populista. Buenos Aires: F.C.E.

Lane, S. T. M. (2009). O que é psicologia social. (editora e livraria Brasiliense, Ed.). Sao Paulo.

Lane, S. T. M., \& Sawaia, B. B. (1991). Community social psychology in Brazil. Applied Psychology, 40(2), 119-142. https://doi.org/10.1111/j.1464-0597.1991.tb01364.x. 
Margot, J. P. (2015). Michel Foucault: La revolución y la cuestión del presente. Praxis filosófica, 41, $193-214$. Martín-Baró, I. (1973). Psicología del campesino salvadoreño. Estudios Centroamericanos, 476-495.

Marx, W., Bornmann, L., Barth, A., \& Leydesdorff, L. (2014). Detecting the historical roots of research fields by reference publication year spectroscopy (RPYS). Journal of the Association for Information Science and Technology, 65(4), 751-764.

Molina, N. (2015). Contra la amnesia y la ingenuidad académica. In E. M. En \& Á. Díaz (Eds.), Psicología Social Crítica e Intervención Psicosocial. Reflexiones y experiencias de investigación (pp. 11-17). Cali: Editorial Bonaventuriana.

Molina, N., \& Estrada, A. M. (2006). Critical construction of psychology in Colombia. Annual Review of Critical Psychology, 5, 342-353.

Montero, M. (2004). Introducción a la psicología comunitaria. Desarrollo, conceptos y procesos. Buenos Aires: Paidós.

Montero, M. (2010). Crítica, autocrítica y construcción de teoría en la psicología social latinoamericana (pp. 177-191).

Montero, M., \& Serrano-García, I. (2011). Historias de la Psicología Comunitaria en América Latina: participación y transformación. Buenos Aires: Paidós.

Mulkay, M. (1981). Action and belief or scientific discourse? A possible way of ending intellectual vassalage in social studies of science. Philosophy of the Social Sciences, 11, 163-171.

Niiniluoto, I. (1991). Realism, relativism, and constructivism. Synthese, 89, 135-162.

Parker, I. (1989). The crisis in Modern Social Psychology, and how to end it. London: Routledge.

Parker, I. (1990). Real things: discourse, context and practice. Philosophical Psychology, 3(2), 37-41.

Parker, I. (1996). Agaisnt Wittgenstein: materialist reflections on language in psychology. Theory \& Psychology, 6(3), 363-384.

Parker, I. (1998). Against postmodernism. Psychology in cultural context. Theory \& Psychology, 8(5), 601-627.

Parker, I. (1999a). Agaisnt relativism in psychology, on balance. History of the human sciences, 12(4), 61-78.

Parker, I. (1999b). Agaisnt relativism in psychology, on balance. History of the human sciences, 12(4), 61-78.

Parker, I. (2004). Slavoj Zizek. A critical introduction. London: Pluto Press.

Parker, I. (2005). Lacanian discourse analysis in psychology: seven theoretical elements. Theory \& Psychology, 15(2), 163-182.

Parker, I. (2007a). Critical psychology: what it is and what it not. Social and Personality Psychology Compass, l(1), 1-15.

Parker, I. (2007b). Revolution in psychology. Alienation to emancipation. London: Pluto Press.

Parker, I. (2011). Lacanian psychoanalysis. Revolutions in subjectivity. Hove: Routledge.

Parker, I. (2012). Discursive social psychology now. British Journal of Social Psychology, 51, 471-477.

Parker, I. (2014). The Crisis in Modern Social Psychology, and how to end it. Abingdon/New York: Routledge.

Parker, I., Potter, J., Gill, R. O. S., \& Edwards, D. (1990). Discourse: definitions and contradictions. Philosophical Psychology, 3(2), 37-41.

Patterson, A., \& Potter, J. (2009). Caring: building a "psychological disposition" in pre-closing sequences in phone calls with a young adult with a learning disability. British Journal of Social Psychology, 48(3), 447465.

Pavón-Cuéllar, D. (2011). La psicología crítica de Ian Parker: análisis de discurso, marxismo trotskista y psicoanálisis lacaniano. Teoría Y Crítica de La Psicología, 1, 42.

Pavón-Cuéllar, D. (2014). The enunciating act and the problem of the real in lacanian discourse. In I. Parker \& D. Pavón-Cuellar (Eds.), Lacan, discourse, event: new psychoanalytic approaches to textual indeterminacy (pp. 35-53). UK: Routledge.

Pérez-Jiménez, D. (2002). Una mirada a las metas y valores de la psicología social-comunitaria: ¿Habremos cerrado la brecha entre la teoría y la práctica? Ponencia presentada en el 49 Convención de la Asociación de Psicología de Puerto Rico, Ponce, Puerto Rico.

Potter, J. (1979). The development of social psychology: consensus, theory and methodology in the British Journal of Social and Clinical Psychology. British Journal of Social Psychology, 20, 249-258.

Potter, J. (1987). Social representations: a conceptual critique. Journal for the Theory of Social Behaviour, 17(4), $471-487$.

Potter, J. (1991). The reflexivity thesis: wrighting the sociology of scientific knowledge. Discourse \& Society, 2(1), 119-120.

Potter, J. (2010a). Contemporary discursive psychology: issues, prospects, and Corcoran's awkward ontology. British Journal of Social Psychology, 49, 657-678.

Potter, J. (2010b). Disciplinarity and the application of social research. British Journal of Social Psychology, 49, $691-701$.

Potter, J. (2011). Disciplinarity and the application of social research. British Journal of Social Psychology, 49(4), 691-701. 
Potter, J. (2012). Re-reading discourse and social psychology: transforming social psychology. British Journal of Social Psychology, 51, 436-455.

Potter, J., \& Litton, I. (1985). Some problems underlying the theory of social representations. British Journal of Social Psychology, 24, 81-90.

Potter, J., Wetherell, M., Gill, R., \& Edwards, D. (1990). Discourse: noun, verb or social practice? Discourse: noun, verb or social practice? Philosophical Psychology, 3(2), 37-41. https://doi.org/10.1080 /09515089008572999.

Reina, M. J. A. (2001). Fin de la ilusión descriptiva: la fiesta de los actos de habla. In Écrire, traduire et représenter la fête (pp. 637-645). Valencia: Universitat de València.

Ruíz, G., \& Enrique, P. (2002). ¿Ontología o teoría del conocimiento? Heidegger crítico del NeoKantismo. Signos Filosóficos, (7), 125-150.

Sabucedo-Camellese, J. M. (1989). Factores psicosociales asociados a las formas de participación política institucional y no institucional. In E. M. Villareal (Ed.), Movimientos sociales (pp. 193-208). San Sebastián: Servicio Editorial Universidad del País Vasco.

Sacks, H., Schegloff, E. A., \& Jefferson, J. (1974). A simplest systematics for the organization of turn-taking for conversation. Language, 50(4), 696-735. https://doi.org/10.2307/412243.

Schegloff, E. A. (1991). Conversation analysis and socially shared cognition. In L. B. Resnick, J. Levine, \& S. D. Behrend (Eds.), Socially shared cognition (pp. 150-171). Washington, DC: APA.

Schegloff, E. A. (1992). On talk and its institutional occasions. In J. J. Gumperz (Ed.), Talk at work. Interaction in institutional settings (pp. 101-134). UK: Cambridge University Press.

Shapin, S. (1984). Talking history: reflections on discourse analysis. Isis, 75(1), 125-130.

Silverman, I. (1977). Why social psychology fails. Canadian Psychological Review, 18(4), 353-358. https://doi. org/10.1037/h0081451.

Sims-Schouten, W., Riley, S. C. E., \& Willig, C. (2007). Critical realism in discourse analysis: a presentation of systematic method of analysis using women's talk of moterhood, childcare and female employment as an example. Theory \& Psychology, 17(1), 101-124.

Shotter, J. (1973). Acquired powers: the transformation of natural into personal powers. Journal for the theory of social behaviour, 3(2), 141-156.

Travis, C., \& Harré, R. (1985). Personal being. Philosophical Quaterly, 35(140), 322-323.

van Eck, N. J., \& Waltman, L. (2010). Software survey: VOSviewer, a computer program for bibliometric mappin. Scientometrics, 84(2), 523-538. https://doi.org/10.1007/s11192-009-0146-3.

Varela, C. R. (2013). The romantic realism of Michel Foucault returning to Kant. Journal for the Theory of Social Behaviour, 43(2), 226-245.

Varela, C. R., \& Harré, R. (1996). Conflicting varieties of realism: causal powers and the problems of social structure. Journal for the Theory of Social Behaviour, 26(3), 313-325.

Villalobos, M. (2013). Enactive cognitive science: revisionism or revolution? Adaptive Behavior, 21(3), $159-167$. https://doi.org/10.1177/1059712313482953.

Wiesenfeld, E. (2000). Entre la prescripción y la acción: La brecha entre la teoría y la práctica en las investigaciones cualitativas. Forum Qualitative Sozialforschung/Forum: Qualitative Social Research, 1, 2.

Publisher's Note Springer Nature remains neutral with regard to jurisdictional claims in published maps and institutional affiliations. 